\title{
CREEP BEHAVIOUR OF A SHORT-FIBRE C/PPS COMPOSITE
}

\section{VEDENJE KRATKIH VLAKEN C/PPS KOMPOZITOV PRI LEZENJU}

\author{
Tomáš Fíla ${ }^{1}$, Petr Koudelka ${ }^{2}$, Daniel Kytýr $\check{r}^{2}$, Jiří Hos ${ }^{1}$, Jan Šleichrt ${ }^{1}$ \\ ${ }^{1}$ Czech Technical University in Prague, Faculty of Transportation Sciences, Konviktská 20, 11000 Prague 1, Czech Republic \\ 2Institute of Theoretical and Applied Mechanics, Academy of Sciences of the Czech Republic, Prosecká 76, 190 00 Prague, Czech Republic \\ xfila@fd.cvut.cz \\ Prejem rokopisa - received: 2014-08-22; sprejem za objavo - accepted for publication: 2015-04-24
}

doi:10.17222/mit.2014.208

\begin{abstract}
Composite materials with a polymeric matrix reinforced by carbon fibres are nowadays widely used as high-tech structural materials with excellent mechanical properties (particularly their stiffness and strength). The application of this type of composite to structural parts exposed to thermal loading has recently been proposed. Such an application requires an investigation and analysis of the mechanical behaviour under long-term exposure to simultaneous thermal and mechanical loading. In this paper the measurements and results of the creep behaviour of a composite with a polyphenylene sulphide matrix reinforced with chopped poly-acrylonitrile carbon fibres (C/PPS) are presented. The measured compound is proposed for use as a structural material for a jet-engine frame in the aerospace industry and the internal parts of aircraft with possible thermal loading. A custom experimental device designed for the creep measurements of composite materials was used for measurements of the developing strain at a constant tensile stress and temperature. Short-term creep tests with continuous strain monitoring were performed at a constant stress level at several elevated temperatures below and above the glass-transition temperature of the matrix. The strain was measured using the digital image correlation (DIC) method. The measured data were processed to find the strain-to-time dependency and the creep-compliance-to-time dependency. The creep-compliance-to-time data were also fitted using Findley's creep law for polymers to evaluate the model parameters and to analyse the applicability of the model for a PPS polymer reinforced with chopped carbon fibres.

Keywords: creep, short fibre composite, C/PPS, Findley's model, DIC
\end{abstract}

Kompozitni materiali s polimerno osnovo, okrepljeno z ogljikovimi vlakni, se dandanes pogosto uporabljajo kot visokotehnološki konstrukcijski materiali z izjemnimi mehanskimi lastnostmi, še posebej to velja za njihovo togost in trdnost. Pred kratkim je bila predlagana uporaba kompozita te vrste za konstrukcijske dele, ki so izpostavljeni toplotni obremenitvi. Takšna uporaba zahteva raziskavo in analizo mehanskega vedenja pri dolgotrajni izpostavljenosti istočasni toplotni in mehanski obremenitvi. Prispevek predstavlja meritve in rezultate deformacijskega vedenja kompozitov z matrico iz polifenilen sulfida, okrepljenega z razcepljenimi poliakrilonitrilnimi ogljikovimi vlakni (C/PPS), ki naj bi se uporabljali kot konstrukcijski materiali za ogrodje reaktivnih motorjev v letalski in vesoljski industriji ter za notranje dele letal, ki so pod potencialno toplotno obremenitvijo. Za merjenje napredovane deformacije pri konstantni natezni obremenitvi in temperaturni obremenitvi, je bila uporabljena posebna preizkusna naprava, izdelana za merjenje deformacije kompozitov. C/PPS vzorci so bili postavljeni $\mathrm{v}$ toplotno komoro in segreti. Vzorci so bili nato s pomočjo stiskalnice izpostavljeni konstantni natezni sili. Kratkotrajni preizkusi lezenja, z nadzorovanjem neprekinjene natezne sile, so bili opravljeni pri konstantnih stopnjah obremenitve pri različnih temperaturah, ki so bile višje ali nižje od temperature prehoda v steklasto stanje osnove. Deformacija vzorca je bila izmerjena z uporabo metode korelacije digitalne slike (DIC). Namen izmerjenih podatkov je bil poiskati odvisnosti deformacije od časovne komponente in lezenja. Podatki o času in sili lezenja so bili usklajeni s Findleyevim zakonom lezenja za polimere za oceno parametrov modela in analizo veljavnosti modela za PPS polimere, ki so okrepljeni razceplenimi ogljikovimi vlakni.

Ključne besede: lezenje, kompozit s kratkimi vlakni, C/PPS, Findleyev model, DIC

\section{INTRODUCTION}

Composite materials with various matrices reinforced by short or continuous fibres are nowadays widely used as general structural materials with good mechanical properties (particularly their stiffness and strength). One of the very popular composite compounds that are widely used in the aviation industry consists of a polyphenylene sulphide (PPS) matrix and carbon-fibre reinforcement. This material, in continuous fibre form, is typically used in the production of external aircraft components because of its excellent mechanical properties, chemical resistance to aerospace fluids and low density. ${ }^{1}$ Composite compounds with carbon fibres and PPS matrices (C/PPS) also have a good resistance to heat and flames. Therefore, they are able to meet the smoke and toxicity requirements of aviation legislation ${ }^{1}$ and recently they have been used for the construction of aircraft's interior parts, particularly seats. ${ }^{1,2}$

Attempts to simplify the fabrication process for aircraft parts and to reach a higher cost efficiency in terms of production have led to the introduction of C/PPS in the form of a material reinforced by chopped or short carbon fibres. ${ }^{3}$ The parts used in the aviation industry, e.g., seats, manufactured using a composite with a short reinforcement can be easily fabricated using injection moulding and their shape can be very complex and thick. ${ }^{3}$ However, such composites consist of unit cells with discrete boundaries, various fibre arrangements and distributions. Thus, these materials exhibit significantly lower strengths and are in comparison with continuousfibre reinforcements susceptible to the occurrence of creep. ${ }^{4}$ For this reason the creep behaviour of short-fibre composites has to be properly described and taken into 
account as one of the most important parameters for an estimation of a part's lifetime.

In this study a series of isothermal creep measurements was performed with the composite compound consisting of a PPS matrix reinforced with short carbon fibres fabricated using an untested method involving heating cables (details of the manufacturing method are classified, and thus only the main features of the method will be described in the text). The tested material is planned to be used for the construction of monocoque shell parts of the fuselage and for structural parts with large volumes (such as engine suspension, etc.) and thin reinforcements with possible thermal loading.

\section{EXPERIMENTAL PART}

Material samples with a dog-bone shape were tested in a custom-designed device for uniaxial creep tests at a constant stress level. The creep was measured on a set of samples at various temperatures above and below the glass-transition temperature of the matrix. The strain was observed using a digital single-lens-reflex (DSLR) camera and evaluated using the digital image correlation technique (DIC). As a result, the strain-time and the creepcompliance-time dependencies were evaluated and the creep behaviour of the tested compound was described.

\subsection{Material}

The material samples were manufactured as a new type of cost-efficient material. The composite compound (Carbon AS4/PPS, TenCate Advanced Composites) consists of a polymeric polyphenylene sulphide (PPS) matrix and chopped carbon fibres with a length of approximately $10 \mathrm{~mm}$. The material was fabricated as a 2.5-mm-thick sheet using the technique of mixing chopped fibres with PPS particles and baking in a mould with heating cables at $310-340{ }^{\circ} \mathrm{C}$ under $4 \mathrm{MPa}$

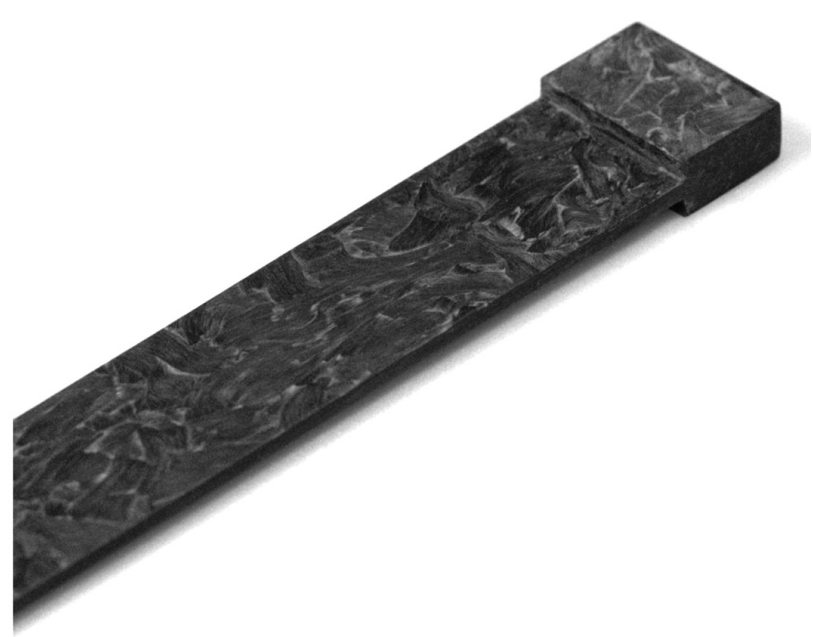

Figure 1: Image of a C/PPS sheet used to prepare a specimen Slika 1: Posnetek C/PPS pločevine, ki je bila uporabljena za pripravo vzorca pressure. The outer parts of the sheet were manufactured with an $8 \mathrm{~mm}$ thickness for the clamping of the samples into sample holders. Part of the sheet is depicted in Figure 1.

\subsection{Specimen preparation}

The dog-bone-shaped specimens were cut from a sheet of material using a water-jet cutting machine. The middle part of the specimen was prepared with a width of $10 \mathrm{~mm}$. The overall length of the specimen was 160 $\mathrm{mm}$, the maximum width was $25 \mathrm{~mm}$ and the thickness of the middle part was $2.5 \mathrm{~mm}$. The maximum distortion caused by the water-jet cutting was experimentally determined to be better than $0.15 \mathrm{~mm}$ (in all dimensions on both surfaces of the specimen). Such a manufacturing tolerance was considered to be sufficient for the experiment and the surfaces were not additionally modified. All the specimens were measured before the test and particular dimensions were used for the evaluation of the experiment. The dimensions were selected to be similar to the dimensions of small longitudinal reinforcements used in, e.g., aircraft seats. The specimen surface was sprayed using an airbrush with a granite effect for better pixel identification in the DIC technique. A specimen with a granite coating is displayed in Figure 2.

\subsection{Experimental setup}

The experimental setup consists of a custom-designed experimental device for the creep measurements and a DSLR camera with accessories.

The creep experimental device was designed for uniaxial creep testing at a constant stress level. The device consists of a heating chamber SFL 3119 (Instron, USA) with a temperature range of $-70{ }^{\circ} \mathrm{C}$ to $350{ }^{\circ} \mathrm{C}$, a rigid structural steel frame, two independent aluminium alloy lever arms with ratio of 1:10 and set of dead weights. The device is equipped with two load cells (VTS Zlín, Czech Republic) with a loading capacity up to $10 \mathrm{kN}$. The strain can be measured in two possible ways: extensometers or DIC. Two custom-designed extensometers (VTS Zlín, Czech Republic) with a maximum measur-

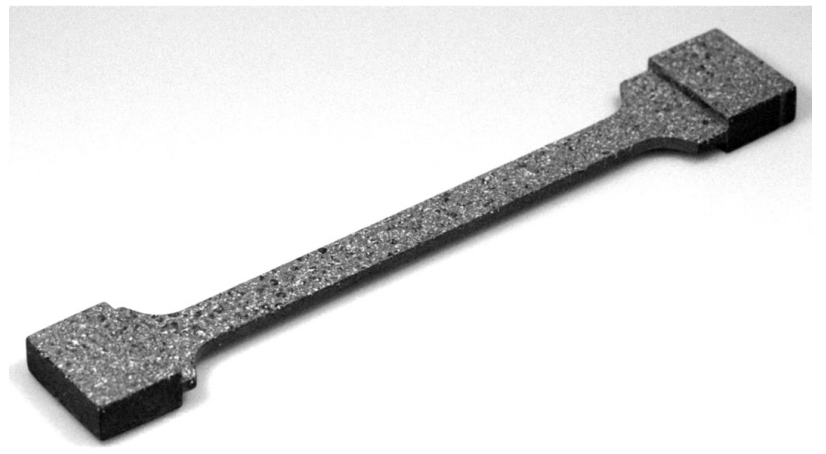

Figure 2: Image of a specimen with sprayed granite coating on its surface

Slika 2: Prikaz vzorca s prevleko iz granita na površini 


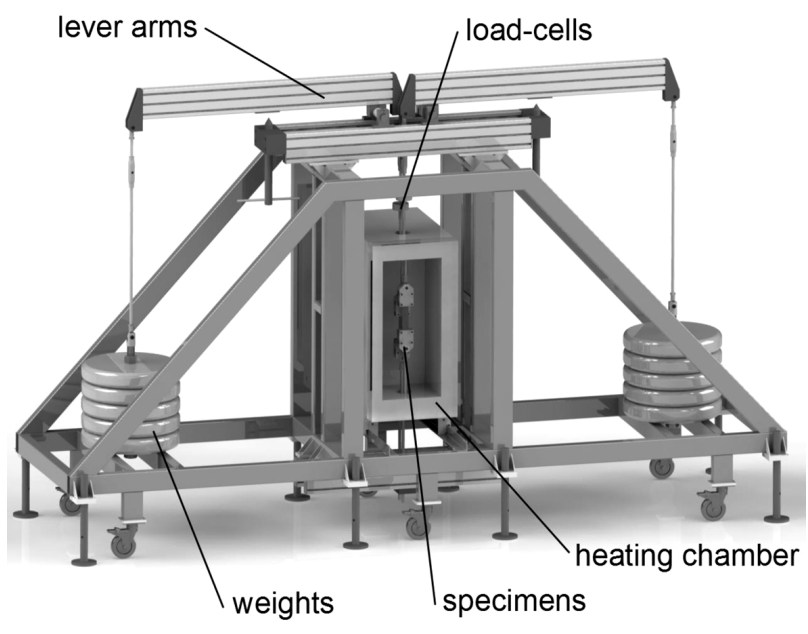

Figure 3: Visualization of the custom-designed device for the creep measurements

Slika 3: Prikaz posebne naprave za merjenje deformacije

able extension of $10 \mathrm{~mm}$ and a heat resistance up to $150{ }^{\circ} \mathrm{C}$ allow the accommodation of two samples in the device's heating chamber and their independent loading. In contrast the DIC allows the measurement of only a single specimen, but it is not limited by the maximum temperature because all of the measuring equipment is situated outside the heating chamber. The experimental device is shown in Figure 3.

The DIC was used as a tool for an evaluation of the strain held in the experiments. The specimen in the heating chamber was observed with a DSLR camera EOS 550D (Canon, Japan) with a macro-objective

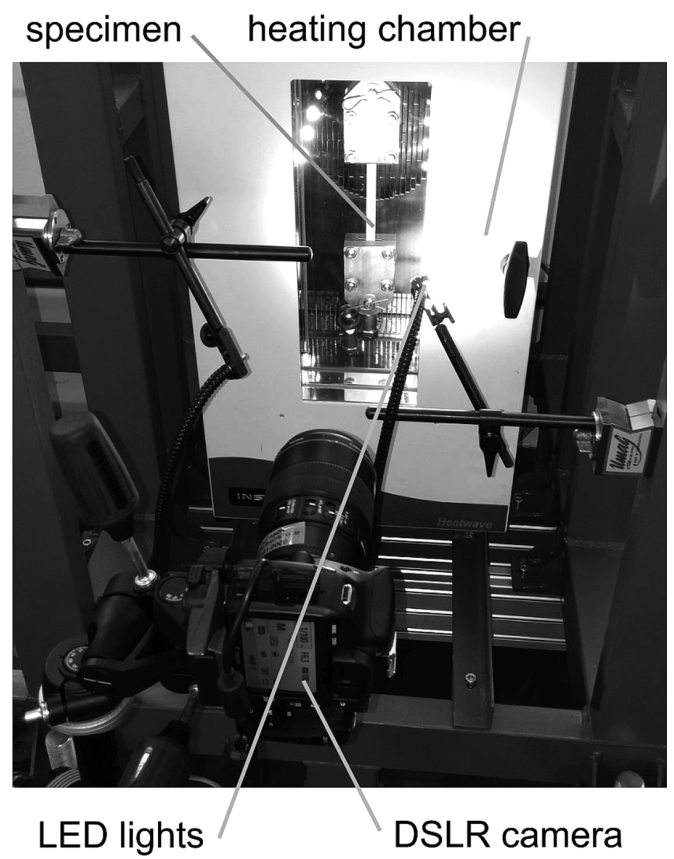

Figure 4: Image of the experimental setup and a specimen mounted in the thermal chamber

Slika 4: Prikaz preizkusnega sklopa in vzorca, ki je bil nameščen v toplotni komori
EF100mm/1:2.8L Macro (Canon, Japan) situated on a tripod in front of the heating chamber. The sample surface was illuminated with a laboratory LED light source KL 2500 (Shott, Germany). The overall view of the experimental setup is shown in Figure 4.

\subsection{Experiment}

Prior to the experiment the specimen was put in the heating chamber and the positions of the illuminators and the camera stand were adjusted. The reference image of the sample surface in the heating chamber was taken to verify the focalization, the field of view and to detect and eliminate possible reflections of illuminating light on the chamber window. The unloaded specimen was then heated to a given temperature and for a 30-min period was held to reach a uniform temperature distribution throughout all the heated parts. After that the image-capturing sequence was started and the specimen was loaded with a constant tensile force of $1.5 \mathrm{kN}$ (one measurement with a loading force of $2.5 \mathrm{kN}$ was also performed). The loading force was selected according to data obtained during quasi-static measurements in tension of specimens with an identical shape. A value of $1.5 \mathrm{kN}$ was situated in a linear elastic region of the material and represented approximately $70 \%$ of the material's yield strength. The creep test was continued until specimen rupture or for at least $20 \mathrm{~h}$. The glasstransition temperature of the matrix material was according to the manufacturer's datasheet approximately $85{ }^{\circ} \mathrm{C}$ and therefore the creep tests were performed at temperatures of $60{ }^{\circ} \mathrm{C}$ (certainly below the glass-transition temperature), $90{ }^{\circ} \mathrm{C}$ (slightly above the glass-transition temperature), $110{ }^{\circ} \mathrm{C}, 130{ }^{\circ} \mathrm{C}$ and $140{ }^{\circ} \mathrm{C}$ (significantly above the glass-transition temperature). Images were taken at equidistant time intervals and were labelled with a unique timestamp for precise synchronization of the DIC and the experiment time. The strain was evaluated from the image sequence using custom DIC software ${ }^{5}$ based on the Lucas-Kanade algorithm. ${ }^{6}$

\section{RESULTS AND DISCUSSION}

The evaluated strain-time dependencies are shown in Figure 5. The creep-compliance-time dependencies were calculated from the data using the following Equation $(1)::^{7,8}$

$$
J_{\mathrm{c}}(t)=\frac{\varepsilon_{\mathrm{c}}(t)}{\sigma_{\mathrm{c}}}
$$

where $J_{\mathrm{c}}(t)$ represents the creep compliance in time $t$, $\varepsilon_{\mathrm{c}}(\mathrm{t})$ is the actual creep strain in time $t$ (excluding the initial strain) and $\sigma_{\mathrm{c}}$ is the applied constant tensile stress. A graph of the creep-compliance-time dependency is shown in Figure 6. 


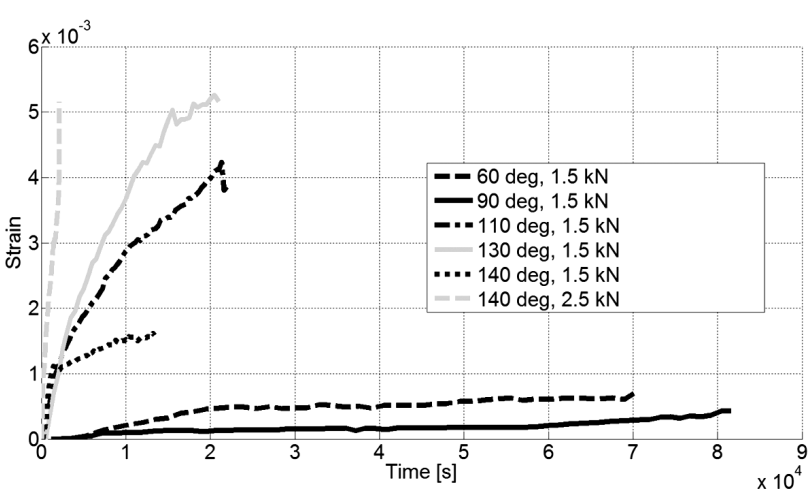

Figure 5: Graph of measured strain-time dependencies Slika 5: Diagram odvisnosti izmerjenih obremenitev in časa

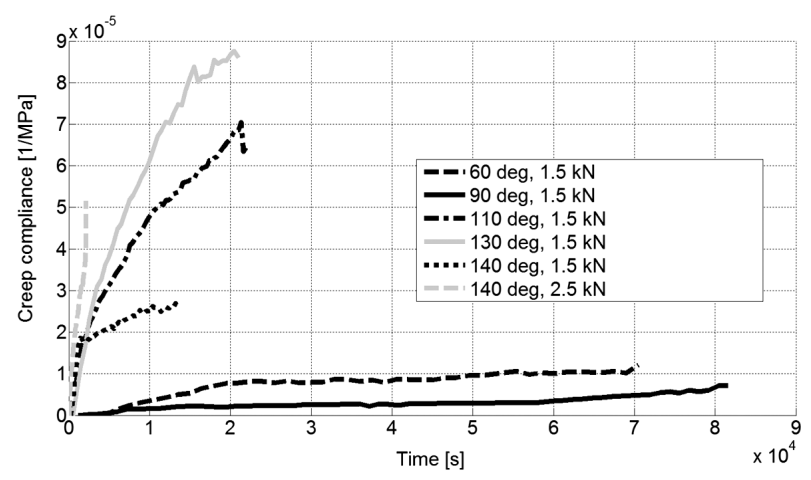

Figure 6: Graph of measured creep-compliance-time dependencies Slika 6: Diagram odvisnosti izmerjenega lezenja od časa

The creep-compliance data were also fitted using Findley's creep law for polymers, assuming steady-state creep behaviour according to the Equation (2):

$$
\overline{J_{\mathrm{c}}(t)}=b_{0} t^{\mathrm{b}_{1}}
$$

where $\overline{J_{\mathrm{c}}(t)}$ represents the predicted creep compliance in time $t$ (in seconds) and $b_{0}, b_{1}$ are material parameters evaluated by a regression of the experimental data. The evaluated regression curves are shown in Figure 7 and the calculated material parameters are summarized in Table 1.

Table 1: Evaluated parameters of Findley's creep model Tabela 1: Ocenjeni parametri Findleyevega modela lezenja

\begin{tabular}{|c|c|c|c|}
\hline Temperature & Loading & \multirow{2}{*}{$b_{0}$} & \multirow{2}{*}{$b_{1}$} \\
\hline$\left({ }^{\circ} \mathrm{C}\right)$ & $(\mathrm{kN})$ & & \\
\hline 60 & 1.5 & $4.432 \times 10^{-10}$ & 0.9386 \\
\hline 90 & 1.5 & $2.286 \times 10^{-9}$ & 0.6818 \\
\hline 110 & 1.5 & $2.419 \times 10^{-7}$ & 0.5711 \\
\hline 130 & 1.5 & $1.271 \times 10^{-7}$ & 0.6712 \\
\hline 140 & 1.5 & $1.078 \times 10^{-6}$ & 0.3475 \\
\hline 140 & 2.5 & $1.832 \times 10^{-7}$ & 0.7044 \\
\hline
\end{tabular}

Based on the experimental data it can be stated that the creep behaviour of the tested material was brittle above the glass-transition temperature. The test of each specimen above this temperature ended with a sudden

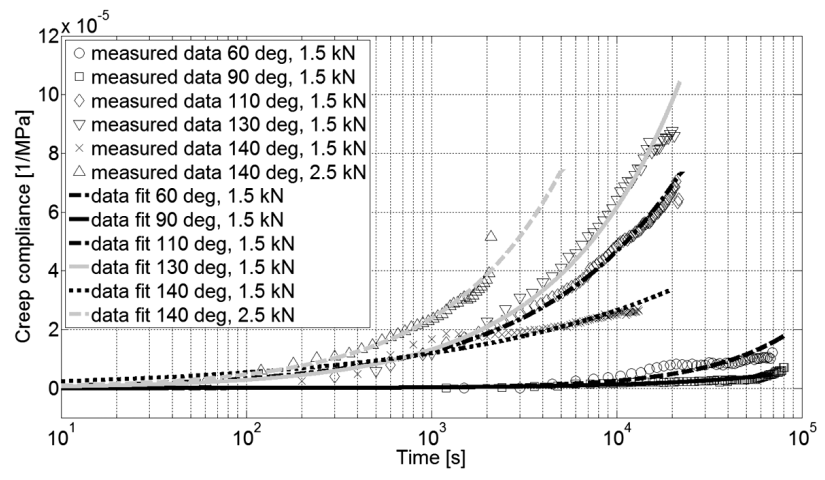

Figure 7: Graph of fits of Findley's creep model on the experimental data

Slika 7: Prikaz prilagoditev Findleyevega modela lezenja na podatke pri preizkusu

specimen rupture after a short time period (max. approx. $6 \mathrm{~h})$.

Creep under (test at $60{ }^{\circ} \mathrm{C}$ ) and slightly above (test at $90{ }^{\circ} \mathrm{C}$ ) the glass-transition temperature can be considered immeasurable because the measured maximum displacements of approximately $10 \mu \mathrm{m}$ correspond only to double the pixel-size of the DIC image (approx. $5 \mu \mathrm{m}$ ) and thus subject to the noise and reliability of the method.

The majority of the measured dependencies agreed with the standard polymer creep theory and their creep strain-rate increased with increasing temperature or loading. A regression analysis showed a good correlation of the experimental data and Findley's creep model for polymers (Figure 7). The fitted model's parameters have different values than usual for clear polymers ${ }^{8-10}$ because of the brittle behaviour of the material and the short times to specimen failure. Still, Findley's creep model can be considered as suitable for a description of the creep behaviour for the used C/PPS compound.

However, disagreement with the basic theory can be seen in the test with a loading of $1.5 \mathrm{kN}$ at a temperature of $140{ }^{\circ} \mathrm{C}$ that exhibited a lower strain rate than expected. The strain rate at the beginning of the test was appropriate for the temperature, but at a strain of approximately $1 \times 10^{-3}$ a sudden decrease was observed and the strain remained low until specimen rupture (Figure 5). Moreover, several specimens ruptured during the initial loading at forces even 3 times lower than the testing force of $1.5 \mathrm{kN}$ and are not presented in the results. This discrepancy was caused by significant imperfections detected in the material's microstructure (missing matrix binder, etc.) caused by an imperfect fabrication process and size effect due to the combination of a random material structure and the small width of the specimen (10 mm). Hence, the delivered material was considered to be unsuitable for parts with small dimensions in terms of structural and thermal loading. 


\section{CONCLUSIONS}

A set of isothermal creep tests with constant loading of the C/PPS composite with chopped fibres was performed. The C/PPS material was fabricated with an innovative technique of baking in a mould using heating cables. The experiments were performed at several different temperatures below and above the glass-transition temperature and the strain was evaluated using the DIC technique. The experimental results showed a good correlation with the standard creep theory for polymers and with Findley's creep law. However, the used fabrication technology brought several imperfections to the material's structure, which together with the size effect caused by small dimensions of the specimen, led to a discrepancy in the results. Thus, the tested material was considered unsuitable for small structural parts exposed to structural and thermal loading and so further improvements to the fabrication process are required.

\section{Acknowledgements}

The research was supported by The Technology Agency of Czech Republic (grant No. TA03010209), by the Grant Agency of the Czech Technical University in Prague (grant No. SGS15/225/OHK2/3T/16) and by RVO: 68378297. All the support is gratefully acknowledged.

\section{REFERENCES}

${ }^{1}$ M. Favarolo, Evaluation of a low cost thermoplastic composite for aircraft interior applications, Proceedings of SAMPE 2010 Conference, Seattle, USA 2010

${ }^{2}$ Composites becoming the standard in aircraft seats, JEC Composite Magazine, 43 (2006) 23, 34

${ }^{3}$ R. Bockstedt, J. Sajna, Low cost composites based on long carbon fiber thermoplastics, Proceedings of SAMPE 1993 Conference, Anaheim, USA, 1993

${ }^{4}$ V. Monfared, M. Mondali, A. Abedian, Steady state creep behaviour of short fiber composites by mapping logarithmic functions (MF) and dimensionless parameter (DP) techniques, Archives of Civil and Mechanical Engineering, 12 (2012), 455-463, doi:10.1016/j.acme. 2012.08.001

${ }^{5}$ I. Jandejsek, J. Valach, D. Vavřik, Optimization and Calibration of Digital Image Correlation Method, Proceedings EAN 2010, Czech Republic, 2010, 121-126, doi:http://hdl.handle.net/11104/0190791

${ }^{6}$ B. Lucas, T. Kanade, An iterative image registration technique with an application to stereo vision, Proceedings of IUW, 1981, 121-130

${ }^{7}$ W. Callister, Fundamentals of Material Science, John Wiley, 2001

${ }^{8}$ S. Vaitkus, I. Gnip, V. Kersulis, S. Vejelis, Prediction of Creep Strain of the Expanded Polystyrene (EPS) in Long-term Compression, Materials Science, 13 (2007) 4, 293-296

${ }^{9}$ Y. Guo, R. Bradshaw, Isothermal physical aging characterization of Polyether-ether-ketone (PEEK) and Polyphenylene sulfide (PPS) films by creep and stress relaxation, Mech Time-Depend Mater, 11 (2007) 1, 61-89, doi:10.1007/s11043-007-9032-7

${ }^{10}$ Y. Guo, R. Bradshaw, Long-term creep of polyphenylene sulfide (PPS) subjected to complex thermal histories: The effect of nonisothermal physical aging, Polymer, 50 (2009) 16, 4048-4055, doi:10.1016/j.polymer.2009.06.046 